Studies in African Linguistics

Volume 26, Number 2, Fall 1997

\title{
CLASS 5 ALLOMORPHY IN CIYAO
}

\author{
Armindo S. A. Ngunga \\ University of California, Berkeley \\ Universidade Eduardo Mondlane
}

Studies of Ciyao, a Bantu language classified as P.21 by Guthrie [1967-71], agree that there are 18 noun classes, each of which determines a primary prefix on the noun, and concord prefixes on elements that agree with head nouns. Most of the primary prefixes have the shape CV-or N- both in Proto-Bantu and in Ciyao. In contemporary Ciyao, class 5 nouns take a prefix which has two allomorphs, the expected CV-di-alternating with the isolated CVV-dii-, posing the problem of how to explain their source and distribution. The purpose of this paper is to document the realization of Ciyao class 5 in detail, and to demonstrate that the di/dii- alternation is prosodically conditioned.

\section{Introduction}

One of the best known characteristics of the Bantu languages is the regular distribution of the nouns into noun classes. Ciyao, a Bantu language classified as P.21 by Guthrie [1967-71], provides a typical example. ${ }^{1}$ Studies of Ciyao [Sanderson 1922, 1954; Whiteley 1961, 1966; Ngunga 1987] are unanimous in agreeing that there are 18 noun classes, each of which determines a primary prefix on the noun

1 Ciyao is spoken in Malawi, Mozambique, Tanzania and, within the last forty years or so, in some regions of Zambia and Zimbabwe due to massive migration of thousands of Yaos from Malawi to those countries in the late 1940s and early 1950s. This paper is based on the Mozambican dialect as spoken by the author and Maria Bernardete. I would like to thank Larry Hyman for his extensive input into the writing of this paper as well as Sharon Inkelas and Sam Mchombo for their valuable comments on an earlier version. I would also like to thank Dete for insightful discussion of the data, as well as Thilo Schadeberg, Robert Botne, and an anonymous reviewer for their interesting comments on the earlier version. However, I remain solely responsible for any errors. Research on Ciyao has been supported in part by the Eduardo Mondlane University (Mozambique) and conducted in the context of the Comparative On-Line Dictionary (CBOLD) project, partially supported by National Science Foundation Grants \#SBR93-19415 and \#SBR96-16330. 
Table 1. Ciyao noun classes

\begin{tabular}{|c|c|c|c|c|c|c|c|}
\hline \multirow[t]{2}{*}{ Class } & \multicolumn{2}{|c|}{ Noun Prefix } & \multicolumn{2}{|c|}{ Vb. AGR } & \multicolumn{2}{|c|}{ Enum. AGR } & \multirow[t]{2}{*}{ Examples } \\
\hline & Ciyao & $\mathrm{PB}$ & Ciyao & $\mathrm{PB}$ & Ciyao & PB & \\
\hline 1 & $\begin{array}{l}\text { mu- } \\
\text { mw- } \\
N^{\prime}-\end{array}$ & ju-mu-2 & ju- & ju- & ju- & (u-) & $\begin{array}{l}\text { muu-ndu jú-gwiúle } \\
\text { mw-aanáce jú-gwiúle } \\
\text { m-palú jú-gwiúle }\end{array}$ \\
\hline 2 & $\begin{array}{l}\text { va- } \\
\text { a- }\end{array}$ & ba-ba- & (v)a & ba- & va- & ba- & $\begin{array}{l}\text { vaa-ndu á-gwiíle } \\
\text { a-palú á-gwiule }\end{array}$ \\
\hline 3 & $\begin{array}{l}\text { mu- } \\
\text { mw- } \\
N^{\prime}-\end{array}$ & gu-mu- & wu- & gu- & wu- & $(\mathrm{u}-)$ & $\begin{array}{l}\text { mu-si wú-gwiúle } \\
\text { mw-éésí wú-gwiúle } \\
\text { n-goómbá wu-gwiúle }\end{array}$ \\
\hline 4 & $\begin{array}{l}\mathrm{mi-} \\
\mathrm{my}\end{array}$ & gi-mi- & ji- & gi- & ji- & (i-?) & $\begin{array}{l}\text { mi-si jí-gwiúle } \\
\text { mi-goómbá ji-gwiule } \\
\text { my-éésí jí-gwiüle }\end{array}$ \\
\hline 5 & $\begin{array}{l}\text { di- } \\
\text { dii- } \\
\text { dy- }\end{array}$ & $\mathrm{di}-\mathrm{j}-$ & di- & di- & di- & i- & $\begin{array}{l}\text { di-véélé dí-gwiúle } \\
\text { dii-jela dí-gwiule } \\
\text { dy-oolá di-gwiulle }\end{array}$ \\
\hline 6 & ma- & ga-ma- & ga- & ga- & ga- & ma- & $\begin{array}{l}\text { ma-véélé gá-gwiúle } \\
\text { ma-jela gá-gwiúle }\end{array}$ \\
\hline 7 & $\begin{array}{l}\text { ci- } \\
\text { c- }\end{array}$ & ki-ki- & ci- & ki- & ci- & ki- & $\begin{array}{l}\text { ci-ló cí-gwíle } \\
\text { c-áálá cí-gwíle }\end{array}$ \\
\hline 8 & $\begin{array}{l}\text { yi- } \\
y-\end{array}$ & bij-bj- & yi- & bj- & yi- & bij- & $\begin{array}{l}\text { yi-ló ý́-gwiủle } \\
\text { y-áálá yí-gwiíle }\end{array}$ \\
\hline 9 & $\mathrm{~N}^{-}$ & ji-n- & ji- & ji- & $\mathrm{ji}-$ & $(\mathrm{i}-?)$ & $\begin{array}{ll}\text { n-juva ji-gwille } & \text { 'the dove fell' } \\
\emptyset \text {-wuuti ji-gwille } & \text { 'the gun fell' }\end{array}$ \\
\hline 10 & $\begin{array}{l}N^{-} \\
\emptyset\end{array}$ & ji-n- & si- & $\mathrm{ji}-$ & si- & $i^{-}$ & $\begin{array}{l}\text { m-balati sí-gwíle (sg.=11) 'the ribs fell' } \\
n \text {-gomó sí-gwíle (sg.=11) 'the lips fell' } \\
n \text {-juva si-gwíle } \quad(\text { sg.=9) 'the doves fell' } \\
\emptyset \text {-wuuti sí-gwíle } \quad(\text { sg.=9) 'the guns fell' }\end{array}$ \\
\hline 11 & $\begin{array}{l}\text { lu- } \\
\text { lw- }\end{array}$ & du-du- & lu- & du- & lu- & du- & $\begin{array}{ll}l u \text {-valati lú-gwiule } & \text { 'the rib fell' } \\
\text { lu-wuudi lú-gwiule } & \text { 'the white hair fell' } \\
\text { lw-aawú lu-gwiule } & \text { 'the net fell' }\end{array}$ \\
\hline 12 & ka- & ka-ka- & ka- & ka- & ka- & $\mathrm{ka}$ & ka-valati ká-gwiúle \\
\hline 13 & tu- & tu-tu- & tu- & tu- & tu- & tu & tu-valati tú-gwüle \\
\hline 14 & wu- & bu-bu- & wu- & bu- & wu- & bu- & wu-lávídi wu-gwiíle \\
\hline 15 & ku- & ku-ku- & ku- & ku- & ku- & ku- & ku-dyá kú-gwiúle \\
\hline 16 & pa- & pa-pa- & pa- & pa- & pa- & pa- & 'the top of a head fell' \\
\hline 17 & ku- & ku-ku- & ku- & ku- & ku- & ku- & ku-ntwé kú-gwiule 'the head-rest fell' \\
\hline 18 & $\begin{array}{l}\mathrm{mu}- \\
\mathrm{N}^{\prime}-\end{array}$ & mu-mu- & mu- & $\mathrm{mu}-$ & mu- & mu- & $\begin{array}{ll}\text { mu-ntwé mú-gwiule 'in the path is clean' } \\
\text { mw-iitala mu-saléele 'in the path is clean' }\end{array}$ \\
\hline
\end{tabular}

2 The first prefix in this column is the augment, a pronominal copy prefixed to noun prefixes having the structure CV-. In many contemporary Bantu languages, the initial $\mathrm{C}$ of the augment has been dropped, thereby creating a VCV-prefix sequence, as in the language names, I-ci-bemba, I-si-zulu, O-lu-ganda, where the initial vowels are augments and the CV-syllables are noun class prefixes.

Abbreviations: $\mathrm{vb}=\mathrm{verb}$, enum.=enumerative, agr.=agreement. 
as well as concord prefixes on elements that agree with head nouns. These noun classes are identified and illustrated in Table 1. Also presented in Table 1 are the Proto-Bantu (PB) forms for both noun and concord prefixes, as reconstructed by Meeussen [1967]. Most of these have the shape CV- or N- both in Proto-Bantu and in Ciyao. As one can see, however, class 5 nouns take a prefix which has two allomorphs in Ciyao: an expected CV-form di-alternating with the CVV-form dii-. The relation between these two allomorphs is the subject of the present study.

Our recent investigation of the Ciyao lexicon is based on a database of 7,714 entries of which there are 3,659 nouns. Of these, 515 are class 5 nouns, out of which 403 take the monomoraic prefix di-, while 112 take the bimoraic prefix dii-. The discovery of these two allomorphs poses the problem of how to explain the source and the distribution of the class 5 allomorphs in contemporary Ciyao. Having noticed the existence of the class 5 prefix dii- in many Bantu languages, Meeussen's [1967] diachronic account is that class 5 nouns were marked by a *di-j-sequence in Proto-Bantu, where *di- is the so-called "augment" and $i-$ the vowel prefix. However, as documented by Kadima [1969], numerous Bantu languages mark class 5 nouns with reflexes of $i$ - rather than with reflexes of *di-. Ciyao is one of the many Bantu languages that has lost the historical augment or "preprefix" (see de Blois [1970]). Thus, although it is likely that Ciyao dii- has its diachronic source in $* \mathrm{di}_{-}-\mathrm{i}-$, such an analysis is not available as a synchronic analysis.

The purpose of this paper is twofold. First, we propose to document the realization of Ciyao class 5 in considerable detail. Second, we shall demonstrate that the inherited system has been restructured in Ciyao in such a way that the di-/ dii- alternation is now prosodically conditioned. The paper is organized as follows: $\S 2$ shows the prosodic conditioning of di-/dii- alternation. $\S 3$ discusses secondary prefixation, while $\$ 4$ presents our conclusions.

\section{Prosodically conditioned allomorphy}

In this section we will demonstrate that the di-/dii-alternation is prosodically conditioned. As was mentioned earlier, Meeussen (1967) reconstructs the class 5 augment+prefix as $*$ di-i-. Since Ciyao has lost the augment in all noun classes, class 5 should be realized currently as the reflex of $*_{j-}$. However, while most noun class prefixes are direct reflexes of the forms reconstructed for PB, neither of the two class 5 prefix allomorphs di-/dii- is a direct reflex of the historical prefix $*_{i-}$. The two forms $\mathrm{di}^{-/} / \mathrm{dii}$ - suggest that class 5 is the only case where an augment has been retained in Ciyao. However, we shall show that bimoraic *di-ihas been restructured as a monomorphemic prefix, with the dii-allomorph being prosodically conditioned.

2.1. Monomoraic noun stems. As evident in Table 1 , the class 5 prefix marks a singular noun. Nouns of this class are pluralized by affixing the class $6 \mathrm{ma}$ - 
prefix which is attached to the stem, as shown in (1). ${ }^{3}$ The noun stems in (1a) are trimoraic, while those in (1b) have more than three moras. Based on these data, we can safely conclude that polymoraic stems in class 5 take the monomoraic prefix di-.

(1) a. Trimoraic stems

Class 5

di-wiíwi

di-kúuga

di-véélé

di-sejele

di-lámúsí

b. Longer stems

di-saamulo

di-pálásila

di-comeela

di-jóngóólo

di-palapaato

di-púlúpúútwa

di-piikanilo

di-váándámá

di-puundúgulú

di-púúluulu

di-sókódikóko

di-pweeteceela 'chicken'

'group of people'

'breast'

'bead apron'

'order'

'comb'

'float'

'game-pit'

'centipede'

'scraping'

'butterfly'

'ear'

'spleen'

'cloud'

'bush'

'husk of rice'

'tomato'
Class $6(\mathrm{pl})$

ma-wiíwi

ma-kúuga

ma-véélé

ma-sejele

ma-lámúsí

ma-saamulo

ma-pálásila

ma-comeela

ma-jóngóólo

ma-palapaato

ma-púlúpúútwa

ma-piikanilo

ma-váándámá

ma-puundúgulú

ma-púúluulu

ma-sókódikóko

ma-pweeteceela

3 Class 6 can, under certain circumstances, be used to mark the plural form of nouns which belong to different classes in order to indicate collectivity. These nouns may or may not have other plural forms. In still other cases, $m a$ - may be attached to nouns which do not have singular forms. It appears that nouns which accept the plural prefix $m a$ - sometimes allow backformation to derive a class 5 singular form marked by one of the allomorphs $d i$ - or dii- as in the following examples:
a) nyuúmba $(9 / 10)$
$\rightarrow \quad$ ma-juúmba (6)
$\rightarrow \quad$ di-juúmba (5)
'house/s'
'many houses (collective)' 'very big house'
b) -
$\rightarrow \quad$ ma-mila
c) lu-soónga $(11 / 10)$
'nasal mucus'
$\rightarrow \quad$ dii-mila (5)
'pointed stick'
d) wu-gadi (14) 'stiff porridge'
e) ci-pyá (7)
'debris/ashes from bush-
$\rightarrow \quad$ ma-soónga (6)
'many pointed sticks'
$\rightarrow \quad$ ma-gadi (6)
$\rightarrow \quad \begin{aligned} & \text { di-soónga (5) } \\ & \text { 'big pointed stick' }\end{aligned}$
$\rightarrow \quad$ dii-gadi (5)
'huge amount of stiff ...' fire' 'yi-pyá (8) dii-pyá (5) 'huge amount of 'debris/ ashes...'

Observe that the class 5 nouns which result from backformation convey a special meaning (augmentative). We shall see that even in such cases, the di-/dii- alternation is prosodically conditioned, i.e., di+CVCV nouns derived by backformation, show the same lengthening opposition. 
Now consider the nouns in (2), whose stems are monomoraic. Differing from the nouns in (1), where we saw that polymoraic stems take the monomoraic class 5 prefix $d i$-, the monomoraic stems in (2) select the bimoraic prefix dii-. We see here the first indication that the $d i-/ d i i-$ alternation is prosodically conditioned.

(2) - CV stems

Singular (cl. 5)

dii-pé 'spear grass'

dii-sí 'side of a river'

dii-wú 'ashes'
Plural (cl. 6)

$\begin{array}{ll}\text { ma-dii-pé } & { }^{*} \text { ma-pé } \\ \text { ma-dii-sí } & *^{*} \text { ma-sí } \\ \text { ma-dii-wú } & *_{\text {ma-wú }}\end{array}$

In addition, we note that the plural of the nouns in (2) is derived by "preprefixing" the plural marker to the singular prefix. At least two hypotheses might be entertained to explain this fact. First, one might hypothesize that plural prefixes cannot be directly attached to monomoraic stems. However, the data in (3), where the singular nouns belong to classes other than class 5 , show that this hypothesis cannot be maintained. Note that there are very few -CV stems; in classes $1 / 2$, for example, there are none at all.

(3) -CV stem (other than class 5)

Singular

mu-si
ci-pi
ci-pó
(3) 'village'

(7) 'darkness'
Plural

$$
\begin{array}{lll}
\text { mi-si }(4) & * m i-m u-s i \\
\text { yi-pi }(8) & * \text { yi-ci-pi } \\
\text { yi-pó }(8) & * \text { yi-ci-pó }
\end{array}
$$

As is evident from these examples, even though the stems are monomoraic, the plural form of the nouns in (3) is obtained by affixing the plural prefix directly to the stem. This process is schematized in (4).
(4) a. $[-s i]_{s g} \rightarrow$ mu-si
b. $[-\mathrm{si}] \mathrm{pl} \rightarrow \mathrm{mi}$-si
c. $\left.\left[[-\mathrm{si}]_{\mathrm{sg}}\right]_{\mathrm{pl}}\right] \rightarrow * \mathrm{mi}-\mathrm{mu}-\mathrm{si}$

We see in (4a-b) what can be regarded as an unmarked relationship between singular and plural forms in Ciyao. Illustrated via classes $3 / 4$, singular $m u$ - and plural $\mathrm{mi}$ - are directly spelled out on the noun stems carrying the features [sg] and $[\mathrm{pl}]$, respectively. Thus, the general (unmarked) situation is where both the singular and the plural prefixes are attached directly to the stem. It thus cannot be the monomoraicity of their stems per se that prevents the examples in (2) from deriving the plural forms by attaching the plural marker directly to the stems. We therefore reject the first hypothesis. 
The second hypothesis to account for the double prefixation in (2) refers to the specific identity of the class 6 plural prefix. Perhaps ma-cannot be affixed to monomoraic stems in general, i.e., independently of the class 5 singular problem. According to this hypothesis, the presence of dii- in the plurals in (2) would be due to a minimality condition that ma- requires at least two moras following it. The data in (5) provide a test of this hypothesis.

(5)
a. ma-nyí (6) 'excrement'
ma-tá (6) 'saliva'
b. ma-wu-pyá 'wild fires' <wu-pyá (14) (*ma-pyá) ma-wu-syó 'foreheads' <wu-syó (14) (*ma-syó)

The nouns in (5a) are the only two class 6 nouns with monomoraic stems found in the database that do not have singular counterparts. ${ }^{4}$ As shown, the class 6 prefix $\mathrm{ma}$ - is attached directly to these stems. If there were a pervasive constraint that ma-must be followed by at least two moras, we might have expected either the repetition of the prefix (*ma-ma-nyí) or reduplication of the stem (*ma-nyinyí) to meet the minimal size requirement. While this may suggest that the "preprefixation" of plural $m a$ - to the singular nouns in (2) is not a property of the class 6 prefix, the examples in (5b) tell a different story. The nouns in (5b) are the only two class 6 nouns with a monomoraic stem derived from a singular other than class 5 -in this case class 14 . As indicated, ma- may not be attached directly to the monomoraic stem, but rather must occur outside the singular prefix $w u-(c l .14)$. Comparing the examples in (5) with those in (2), we arrive at the following generalization: a derived plural in class 6 requires that ma- be followed by at least two moras. So, what we have in (2) and (5b) can be represented as in (6), below.
(6) a. [-pé $]_{s g} \rightarrow$ dii-pé
$[- \text { pyá }]_{\text {sg }} \rightarrow$ wu-pyá
$\begin{array}{ll}\text { b. }[- \text { pé }]_{\mathrm{pl}} & \rightarrow{ }^{*} \text { ma-pé } \\ {[- \text { pyá }]_{\mathrm{pl}}} & \rightarrow{ }^{*} \text { ma-pyá }\end{array}$
c. $\left.\left[[-p e ́]_{\text {sg }}\right]_{\text {pl }}\right] \rightarrow$ dii-pé $\rightarrow$ ma-dii-pé [[pyá $\left.\left.]_{s g}\right]_{\mathrm{pl}}\right] \rightarrow$ wu-pyá $\rightarrow$ ma-wu-pyá
d. $[- \text { nyí }]_{\mathrm{pl}} \rightarrow$ ma-nyí [-tá $]_{\mathrm{pl}} \rightarrow$ ma-tá

In (6a) we see that the singular prefixes dii-and $w u$-can be spelled out directly onto a stem which is marked [sg]. In (6b), however, we see that one cannot derive the class 6 plurals directly from a stem marked [pl]. Instead, as shown in (6c), the singular is first spelled out with dii- and wu-, based on the

\footnotetext{
4 This database was originally extracted from Sanderson [1954], which I marked for vowel length and tone, revised, added words to, and entered into Filemaker Pro ${ }^{\mathrm{TM}}$ with additional fields for noun classes, perfective verb stems, etc. At the time of the writing of this paper, the resulting Ciyao dictionary consists of 7,714 entries, of which 3,659 are nouns. I would like to thank John Lowe, without whose help this effort could not have been realized.
} 
stem feature [sg]. This singular then serves as input to the spelling out of the [pl] feature as ma-. This "spell-out" rule does not apply to "inherent" (i.e., nonderived) prefixes such as the two inherent class 6 nouns in (6d), which have no corresponding singulars. The plural of these, as illustrated in (6d), are derived directly from the stem, as we proposed in (4) for both singular and plural classes other than class 6.5

Returning to the class 5 prefix, it is important to note that di-/dii- allomorphy is an exclusive property of class 5 nouns and not of other syntactic categories which take class 5 concord. That is, there is no di-/dii- alternation when the class 5 prefix is attached to demonstratives, verbs, or other parts of speech, even when the following stem is monosyllabic, as illustrated in (7).

(7) a. Demonstratives

dí-vaatá di-la

5-duck 5-that

di-saamulo di-la

5-comb 5-that

b. Adjectives

di-wiiwí dyá dí-wé

5-chicken 5.that 5-dead

di-vaatá dyá dí-pyé

5-duck 5.that 5-dead

c. Numerals

di-vaatá di-mo

5-duck 5-one

dii-saamulo dí-mo

5-comb 5-one

d. Subject marker (SM)

di-wiiwí cí-dí-dye

5-chicken FUT-5-eat

di-saamulo cí-dí-pye

5-comb FUT-5-burn 'that duck'

'that comb'

(cf. *dii-la)

(cf. *dii-la)

'dead chicken'

(cf. *díi-wé)

'burnt duck'

(cf. *díí-pyé)

'one duck'

(cf. *dii-mo)

'one comb'

(cf. *dii-mo)

'the chicken will eat' (cf. *dii-dye)

'the comb will burn' (cf. *dii-pye)

${ }^{5}$ There are, of course, other ways to derive this effect, including non-derivational ones. Larry Hyman (pers. comm.) has thus suggested that these facts could be nicely handled by invoking the "correspondence theory" of OT (McCarthy and Prince [1995]: There is a (violable) bimoraic stem constraint requiring class $6 \mathrm{ma}$ - to be followed by at least two moras. When a stem is monomoraic, this constraint is satisfied by invoking the corresponding singular. Where there is no corresponding singular, such correspondence, of course, cannot be invoked, and the result is a violation of the bimoraic stem constraint. 
e. Object marker (OM)

cí-tú-di-pé di-wiíwi 'we will give the chicken' (cf. *cí-tú-dii-pé) FUT-we-5-give 5-chicken

cí-tú-di-dyé dí-vaáta 'we will eat the duck' (cf. *cí-tú-dii-dyé) FUT-we-5-eat 5-duck

In (7) the class 5 prefix, in boldface, is attached to the monomoraic stems of a demonstrative (7a), an adjective (7b), and a numeral (7c). In (7d) and (7e), the class 5 prefix appears on verbs, as subject marker and object marker, respectively. As one can see, $d i$ - is the only allomorph allowed in spite of the size of the stems. 6 Thus, there is something very specific about the class 5 prefix diithat occurs exclusively before monomoraic noun stems.

This having been said, we should note that there is one contextreduplication - in which the final vowel of all demonstratives is lengthened, in which case the extra mora functions as a "bridge" between the base and the reduplicant, as in (8).
(8) a-vá-á-vá
'these very $\mathrm{X}(\mathrm{cl} .2)$ '
a-dí-í-dí
'this very $\mathrm{Y}(\mathrm{cl} .5)$ '
a-mú-ú-mú
'in this very $\mathrm{Z}$ (cl. 18)'

The capital letters X, Y, Z, in (8) stand for any nouns belonging to classes 2, 5, and 18 , respectively. Thus, the length of the final vowel of the base cannot be regarded as a property of class 5 , since it occurs with all prefixes in this context.

For comparison, we present the corresponding plurals of the forms in (7), with the exception of numerals, in (9).

(9)

a. Demonstratives

ma-vaatá ga-la

6-duck 6-DEM

ma-saamulo gá-la

6-comb 6-DEM 'those ducks' (cf. *ga-dii-la)

'those combs' (cf. * ga-dii-la)

6 Note that a bimoraic dii- may appear in the verb complex as a reflexive marker. This reflexive -dii-, which should not be confused with the class 5 allomorph -dii-, is the same for all nouns regardless of class, as illustrated in the following examples:

(a) mw-aadí ju-kú-dii-totela deléesi 'the girl (cl.1) has sewn herself a dress'

(b) n-ciimbo wu-dj́-kámwíile nciwúnu 'the old baboon (cl.3) has grabbed itself on the hips'

(c) dii-janí dí-kú-dí-páka wútope 'the baboon (cl.5) is smearing itself with mud'

(d) c-oómé cí-díi-potéece 'the cat (cl.7) has hurt/injured itself'

As shown, reflexive -díi- is realized as such regardless of the number of moras following it in the verb stem. Interestingly, Hyman and Ngunga [1994] present a tonal argument in favor of representing the reflexive as bipartite: $-d i-i$. 
b. Adjectives

$\begin{array}{lll}\text { ma-wiiwí gá gá-wé } & \text { 'dead chickens’ } & \text { (cf. *gá-díi-wé) } \\ \text { 6-chicken 6.that 6-dead } & & \\ \text { ma-vaatá gá gá-pyé } & \text { 'burnt ducks' } & \text { (cf. *gá-díi-pyé) } \\ \text { 6-duck 6.that 6-dead } & & \end{array}$

c. Subject marker
ma-wiiwí cí-gá-dye
6-chicken FUT-6-eat
'the chickens will eat' (cf. *ga-dii-dye)
ma-saamulo cí-gá-pye
'the combs will burn'
(cf. *ga-dii-pyẽ)
6-comb FUT-6-burn

\section{d. Object marker}

cí-tú-ga-pé má-wiíwi

FUT-we-6-give 6-chicken

cí-tú-ga-dyé má-vaáta 'we will eat the ducks' (cf. *cí-tú-ga-dii-dyé) FUT-we-6-eat 6-duck

The agreement marker of class 6 nouns is ga- and not ma-. As can be seen in (9), ga- is attached directly to the monomoraic stems of demonstratives, verbs, and adjectives. That is, it does not require the presence of the class 5 singular marker as is the case of class 6 plural nouns with monosyllabic stems. If this had been the case, the incorrect starred forms in parentheses would have been derived. Another important point to note is that, although adjectives might be expected to have the same prefixal morphology as nouns, the examples in (9a-b) show that adjectival inflection is essentially the same as demonstrative inflection (e.g., ju- not mu-, and ga-not ma-, in classes 1 and 6, respectively).

2.2. Bimoraic noun stems. To summarize thus far, the allomorph dii- is used before class 5 monomoraic noun stems. In addition, dii- is present in the corresponding class 6 plurals, because plural ma- requires that at least two moras follow. This effect of monomoraic stems is not present in other parts of speech (demonstratives, adjectives, numerals, verbs), which take exclusively the allomorph $d i-$, as do noun stems having three or more moras.

Thus far nothing has been said about bimoraic noun stems. As shown in (10), these also take the allomorph dii- in class 5. In (10a) we see that dii-is not retained in the corresponding plurals. Instead, the prefix ma-is attached directly to the stem since the latter has the requisite two moras. A similar situation is seen in (10b), where the prefix $w u$ - of class 14 nouns also drops when the class 6 plural prefix ma- is affixed. 
(10) - CVCV stems
a. Class 5
dii-tivi
'valley'
Class 6 (pl.)
dii-túnu
'hyena'
ma-tivi
dii-jela 'hoe'
dii-jóká 'snake'
ma-túnu
dii-janí 'baboon'
ma-jela
ma-jóká
ma-janí
b. Class 14
wu-gadi 'stiff porridge'
Class 6 (pl.)
wu-vígó 'game-fence'
ma-gadii
wu-tope 'mud'
ma-vígó
ma-tope
Wu-nyólo 'metal chain'
ma-nyólo
wu-kuní 'bird's tail'
ma-kuní

These data, along with those in (1) and (2), provide us with evidence that the $\mathrm{di}$-/dii- alternation is conditioned by the number of moras in the stem. That is, as we saw in (1), if the stem has more than two moras, the class 5 prefix is monomoraic. But if, on the other hand, the stem is at most bimoraic, as in (2) and (10), the class 5 prefix is bimoraic. As for the plural forms, it was mentioned above that ma-cannot derive plural nouns (from singular) by its direct prefixation to the monomoraic stems, in which case the prefix ma-is preprefixed to the dii-CV and $w u-C V$ nouns in (2) and (5), respectively. The plural forms of the nouns in (10) do not keep their singular marker because their stems satisfy the minimality requirement the input must satisfy before they are pluralized: bimoraic stem.

While it is largely true that the di-/dii- alternation is prosodically conditioned, there is one exceptional case of a -CVCVVNCV stem which inexplicably takes the bimoraic prefix dii-, as shown in (11).

\section{(11) - CVCVVNCV stem}

Class 5

dii-pujuungu 'vapor, steam, hot air'
Class 6 (pl.)

ma-pujuungu

This is the only such case out of 112 class 5 nouns which takes a bimoraic prefix. In the plural form, the bimoraic singular prefix is "replaced" by a monomoraic ma- as in all other cases where the class 5 noun prefix is at least bimoraic. 7

7 Thilo Schadeberg (per. comm.) suggested to me that the length of the class 5 prefix in dii-pujuungu "would be explained if it were a compound: dii-pu-juungu", although - $p u$ - does not exist as a noun stem in the language. This proposal is an interesting one for it implies that the lengthening of the class 5 prefix sees the internal structure of the compound. However, although it seems to work for this 
2.3. NC-initial stems. For the sake of completeness, let us consider a very different source of prefix length, NC-stems, illustrated by the examples in (12).

(12) -NC...stems

a. Class 5

$\begin{array}{ll}\text { dii-mbáciiga } & \text { 'swollen gland' } \\ \text { dii-mbanaanga } & \text { 'splendor' } \\ \text { dii-ngáanje } & \text { 'rind of corn-stalk' } \\ \text { dii-ngóleenga } & \text { 'trace of liquid on body' } \\ \text { dii-njawuule } & \text { 'kind of dance' }\end{array}$

Class 6 (pl.)

maa-mbáciiga

maa-mbanaanga

maa-ngáanje

maa-ngóleenga

maa-njawuule

b. Other classes

$\begin{array}{lll}\text { muu-ndálaanga } & (3) & \text { 'kind of dance' } \\ \text { mii-ngúti } & (4) & \text { 'kind of tree' } \\ \text { cii-ndógoodya } & (7) \quad \text { 'fruit of a rubaceous tree' } \\ \text { yü-ndógoodya } & (8) \quad \text { 'fruits of a rubaceous tree' } \\ \text { luu-ngumbisi } & (11) & \text { 'poor sight' } \\ \text { muu-ngokwe } & (18) & \text { 'in the granary' }\end{array}$

Since the stems of the examples in (12a) are polymoraic, the dii- allomorph is unexpected. However, these nouns share the property of having a homorganic nasal+consonant (NC) sequence in stem-initial position. In many Bantu languages, including Ciyao, homorganic nasals condition preceding vowel length by a process of compensatory lengthening [Clements 1986, Hayes 1989, Hubbard 1993, 1994, 1995, Hyman and Katamba 1997, Maddieson 1993, Maddieson and Ladefoged 1993], further illustrated by the examples in (12b). Here, then, the vowel length in the prefixes in (12) is conditioned by the nature of the following segment. That is, dii- in (12a) derives from / di-/ when the latter is followed by a moraic nasal (Hyman and Ngunga 1997 [this issue]).

Other evidence for this is the fact that the vowel of the plural prefix ma- is also lengthened in this position. As we saw previously, prefix length conditioned by the mora count of the noun stem is an exclusive feature of the class 5 prefix, other prefixes remaining monomoraic. However, in (12a) we have maa- (cl.6), and in (12b) muu- (cl.3, 18), mii- (cl. 4), cii- (cl.7), yii- (cl.8), and luu- (cl.11),

particular case, other examples in which we find actual compounding do not support it. Consider the following examples:

a. di-wúmáámbula (<-wúmá + mbula) 'bleed at noses'

b. di-káláángulo (<-kálá + ngulo) 'sore throat'

In these examples we have clear cases of compounds where the stem of the first member has the structure-CVCV. The fact that the prefixes of these compound nouns fail to lengthen tells us that unlike Schadeberg's suggestion, the process treats compounds like underived nouns with polysyllabic stems, and does not care about their internal structure. 
which suggests that vowel length in all the examples in (12) is conditioned by the same environmental factor, the initial NC sequence of the stem.

With other noun stems, however, prefix lengthening fails to apply, even though the phonological environment is similar to that observed in (12). As in (12), the prefix precedes a stem-initial NC sequence, yet the prefix vowel does not lengthen as it does in the examples in (12).

Singular Plural

a. -NCVVCV stem

(cl.5)

di-mbaala

'gruel'

(cl.6)

di-mboonda

'edible gourd'

ma-mbaala

di-ndoóndwa

'drop'

ma-mboonda

di-nduútu

'popped corn'

ma-ndoóndwa

di-ngoole

'coconut'

di-ngwíita

di-mbooko

'bracelet or anklet'

'ophtalmia'

ma-nduútu

ma-ngoole

ma-ngwíita

ma-mbooko

b. $-\mathrm{NCV}$... stem

(cl.7)

ci-mbádi

ci-mbandíingwa

ci-ngelengeele 'unjustified expectation'

'piece of broken gourd' 'bell' (cl.8)

yi-mbádi

yi-mbandíngwa

yi-ngelengeele

(cl.13)

tu-ndúndúdimya

\section{(cl.12)}

ka-ndúndúdimya 'hillock'

One factor inhibiting lengthening of the prefix vowel appears to be the presence of a long vowels in the stem-initial syllable, as suggested by the examples in (13a). While we cannot predict with complete certainty which initial NC sequences will condition lengthening of the prefix vowel, with very few exceptions, the existence of a long vowel in the initial syllable of the stem precludes lengthening of the prefix vowel (Ngunga 1995). 8

In (13b) we have nouns from other classes with homorganic nasal sequences in stem-initial position and short vowel in the first syllable. Even though all the conditions are apparently met for compensatory lengthening to apply to the prefix vowel, it does not. This failure of compensatory lengthening to apply reveals that what we actually have in stem-initial position in (12) and (13) are two different

\footnotetext{
8 From this point of view, the noun dii-ngáanje (pl.: maa-ngáanje) 'rind of corn stalk' (12a), which has all the characteristics of the nouns in (13a) except that it takes a bimoraic prefix, is an exceptional case in having a moraic nasal followed by a long vowel in the next syllable.
} 
kinds of preconsonantal nasals in Ciyao. As argued by Hyman and Ngunga [1997 (this issue)], nouns such as those in (12) have moraic preconsonantal nasals in stem-initial position which give up their moras in favor of the prefix vowel, allowing it to lengthen. In (13) the stem-initial preconsonantal nasals are nonmoraic and therefore do not trigger the lengthening of the prefix vowel. In the following table we provide the statistics of the class 5 nouns with preconsonantal nasals in stem-initial position.

Table 2. Statistical account of the distribution of class 5 allomorphs before NC-initial stems.

\begin{tabular}{|l|c|c|c|}
\hline \multirow{2}{*}{$\begin{array}{c}\text { Class 5 } \\
\text { Allomorphs }\end{array}$} & \multicolumn{2}{|c|}{ Noun stem shapes } & Total \\
\cline { 2 - 3 } & -NCVV(N)CV & -NCVCVV(N)CV & \\
\hline di- & 18 & - & 18 \\
\hline dii- & 1 & 5 & 6 \\
\hline Total & 19 & 5 & 24 \\
\hline
\end{tabular}

Table 2 shows that the distribution of di-/dii- before NC-initial stems is conditioned by the length of the stem-initial syllable. That is, if the stem-initial syllable is long (e.g., -NCVV...), the vowel of the prefix is short (di-), but if the stem-initial syllable is short (-NCVC...), the vowel of the prefix is long (dii-). Out of the 19 class 5 nouns with -NCVV...-initial stems, eighteen select the short class 5 allomorph $\mathrm{di}$ - and, exceptionally, one selects the long class 5 allomorph dii-. In contrast, all of the five nouns with -NCVC... in stem-initial position select long class 5 allomorph (dii-). Thus, Table 2 demonstrates that, just as in the cases previously discussed, before -NC-initial stems, the length of the class 5 prefix vowel is highly predictable. In the next section we discuss the affixation of class 5 allomorphs before vowel-initial stems.

2.4. -VCV stems. Let us consider class 5 nouns that have -VCV stems, as illustrated in (14). The nouns in (14a) have a high front vowel in stem-initial position; those in (14b) begin with a non-front vowel. The last two nouns in (14b) have no plural forms and were included here for the sake of exhaustiveness. It should be pointed out that there are no non-derived vowel-initial stems longer than those given in (14).

Since the stems of the class 5 nouns in (14) are bimoraic, their class 5 prefix should in principle be dii-. However, it is not possible to test this hypothesis, since a trimoraic combination of /dii+ V/ would in any case have to be pared down to conform with the bimoraic maximum on Ciyao syllables. It should also be pointed out that the /i/ of the prefix glides to [y] before vowels other than $/ \mathrm{i} /$. 
(14) - VCV stems

Singular

$\begin{array}{clll}\text { a. dí-íná } & \text { 'name' } & \text { mééná } & (</ \mathrm{ma}+\mathrm{ina} /) \\ \text { dí-ínó } & \text { 'tooth' } & \text { méénó } & (</ \mathrm{ma}+\mathrm{ino} /) \\ \text { dí-ísó } & \text { 'eye' } & \text { méésó } & (</ \mathrm{ma}+\mathrm{iso})\end{array}$

Singular

Plural

b.

$\begin{array}{lllll}\text { dy-aája } & (</ \text { di-ája/) } & \text { 'African breadfruit' } & \text { ma-ája } & (</ \text { ma-ája/ }) \\ \text { dy-oóla } & (</ \text { di-óla/) } & \text { 'frog' } & \text { m-oóla } & (</ \text { ma-óla/ }) \\ \text { dy-uúngu } & (</ \text { di-úngu/) } & \text { 'pumpkin' } & \text { m-oóngu } & (</ \text { ma-úngu/ }) \\ \text { dy-úúvá } & (</ \text { di-úvá/) } & \text { 'sun, day' } & \text { m-óóvá } & (</ \text { ma-úvá/) } \\ \text { dy-óósí } & (</ \text { di-ósí/) } & \text { 'smoke' } & & \\ \text { dy-óogo } & (</ \text { di-ogo/) } & \text { 'first bath after circumcision' } & \end{array}$

In (15) we see how the forms in (14) are derived. We begin in both (15a) and (15b) with sequences of $d i$-followed by a -VCV stem. Had we begun with dii-, we would most likely have lost one of the two moras of the prefix when it is followed by a vowel-initial stem. In (15a) the /i/ of $d i$-joins the initial /i/ of the stem /-ina/ to form a bimoraic syllable [dii]. In (15b) the vowel /i/ of the prefix glides to [y] and the following non-high front vowel is compensatorily lengthened. The result is a bimoraic syllable [dyaa].
(15) a.
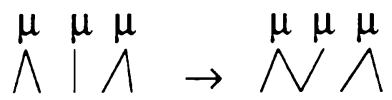
di in a
d i n a
b. $\bigwedge_{\mathrm{di} \text { a ja }}^{\mu \mu}$

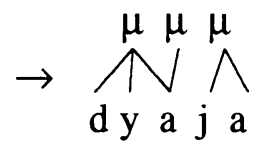

In the case of the corresponding singular forms, the /a/ of ma-fuses with the initial / $\mathrm{i} /$ of the nouns stems in (14a), while it deletes before other vowels in (14b). What is important for our understanding of the problem at hand is that ma- is not added to fused class 5 prefixes to form the plural. That is, we do not obtain *ma-dí-íná, *ma-dy-áaja, etc.

The discussion developed so far can be summarized as follows. The class 5 prefix in Ciyao has two allomorphs, $d i$ - and dii-, whose distribution is determined by the number of moras in the stem. With the exception reported in (11), no stem with more than two moras selects the bimoraic prefix, although this and other prefixes may acquire a long vowel if followed by a moraic nasal. In order to further test the proposed prosodic conditioning of dii-, we consider secondary prefixation in the next section. 


\section{Secondary prefixation}

In this section we examine the so-called secondary prefixation which refers to the processes of diminutivization and locativization.

3.1. Diminutivization of class 5 nouns. The singular class 12 prefix (ka-) and its corresponding plural class 13 prefix ( $t u-)$ are diminutivizers in Ciyao. In general these prefixes occur in the place of the inherent noun class prefix of the input (non-diminutive) noun. This process can be transparently observed in (16), where there are polymoraic-CVVCV stems in (16a), longer stems in (16b). The diminutive prefixes are attached directly to the noun stems, "replacing" the inherent singular and plural prefixes.

(16) Class 5

a. Trimoraic stems

$\begin{array}{ll}\text { di-wiíwi } & \text { 'chicken' } \\ \text { di-kúuga } & \text { 'group of people' } \\ \text { di-sejele } & \text { 'bead apron' } \\ \text { di-lámúsí } & \text { 'order' }\end{array}$

Class 12 (sg.)

ka-wiíwi

ka-kúuga

ka-sejele

ka-lámúsí
Class 13 (pl.)

tu-wiíwi

tu-kúuga

tu-sejele

tu-lámúsí

b. Longer stems

$\begin{array}{llll}\text { di-saamulo } & \text { 'comb' } & \text { ka-saamulo } & \text { tu-saamulo } \\ \text { di-pálásila } & \text { 'float' } & \text { ka-pálásila } & \text { tu-pálásila } \\ \text { di-piikanilo } & \text { 'ear' } & \text { ka-piikanilo } & \text { tu-piikanilo } \\ \text { di-puundúgulú } & \text { 'cloud' } & \text { ka-puundúgulú } & \text { tu-puundúgulú } \\ \text { di-sókódikóko } & \text { 'husk of rice' } & \text { ka-sókódikóko } & \text { tu-sókódikóko } \\ \text { di-pweeteceela } & \text { 'tomato' } & \text { ka-pweeteceela } & \text { tu-pweeteceela }\end{array}$

Examples of diminutivization of class 5 nouns whose stems have a preconsonantal nasal in initial position are given in (17). As in (16), the diminutive prefixes in (17) are also attached directly to the noun stem. Compensatory lengthening yields kaa-/tuu-forms of the diminutive prefixes (17a) where the noun stems begin with moraic nasal. In (17b) the rule does not apply, since the preconsonantal nasal of these stems is non-moraic.

(17) -NC initial stems

Class 5

a. dii-mbáciiga dii-mbanaanga

dii-ngáanje dii-ngóleenga

'swollen gland'

Class 12 (sg.)

Class 13 (pl.)

kaa-mbáciiga tuu-mbáciiga 'splendor' kaa-mbanaanga 'rind of corn-stalk' kaa-ngáanje tuu-mbanaanga tuu-ngáanje 'trace of liquid kaa-ngóleenga tuu-ngóleenga dii-njawuule on the body' 'kind of dance'

kaa-njawuule

tuu-njawuule 


$\begin{array}{llll}\text { Class } 5 & & \text { Class 12(sg.) } & \text { Class 13 (pl.) } \\ \text { b. di-ngwíita } & \text { 'bracelet' } & \text { ka-ngwíita } & \text { tu-ngwíita } \\ \text { di-mbaala } & \text { 'gruel' } & \text { ka-mbaala } & \text { tu-mbaala } \\ \text { di-mboonda } & \text { 'edible gourd' } & \text { ka-mboonda } & \text { tu-mboonda } \\ \text { di-ndoóndwa } & \text { 'drop' } & \text { ka-ndoóndwa } & \text { tu-ndoóndwa } \\ \text { di-nduútu } & \text { 'popped corn' } & \text { ka-nduútu } & \text { tu-nduútu } \\ \text { di-ngoole } & \text { 'coconut' } & \text { ka-ngoole } & \text { tu-ngoole } \\ \text { di-mbooko } & \text { 'ophtalmia' } & \text { ka-mbooko } & \text { tu-mbooko }\end{array}$

Now contrast the above situation with the examples in (18). Even though the prefixes of the nouns in (18) are bimoraic, their corresponding diminutive is realized in the same manner as observed in (16) and (17b), where ka- (singular) and $t u$ - (plural) occur in the place of the classes 5 and 6 primary prefixes, respectively. Once again it is only the class 5 prefix that shows prosodic conditioning of a long vowel allomorph.

(18) Class 5

a. -CVCV stems

dii-tivi

dii-jóká

dii-túnu

dii-jela

dii-janí

'valley'
'snake'
'hyena'
'hoe'
'baboon'

Class 12 (sg.)

Class 13 (pl.)

b. -CVCVVNCV stem

dii-pujuungu 'vapor, hot air' ka-pujuungu

tu-pujuungu

Now consider the forms in (19), in which nouns having stem-initial vowels diminutivize by adding the diminutive prefix outside the inherent prefix. ${ }^{9}$ It is important to observe that in the plural forms there are two ways to express diminutivization, both accepted by the native speakers.
(19) $\mathrm{Cl} .5$ (sg.)
Cl.12 (sg.)
Cl.13 (pl.)
Cl.13 (pl.)
-VCV stems

$\begin{array}{ll}\text { di-íná } & \text { 'name' } \\ \text { dí-ínó } & \text { 'tooth' } \\ \text { di-ísó } & \text { 'eye' } \\ \text { dy-áaja } & \text { 'African breadfruit' } \\ \text { dy-oóla } & \text { 'frog' } \\ \text { dy-uúngu } & \text { 'pumpkin' } \\ \text { dy-úúvá } & \text { 'sun, day' }\end{array}$
ka-dí-íná
ka-dí-ínó
tu-di-íná
tu-dí-ínó
(alternative)
ka-dí-ísó
ka-dy-aája
tu-dí-ísó
tu-dy-aája
ka-dy-oóla
tu-dy-oóla
ka-dy-uúngu
tu-dy-uúngu
ka-dy-úúvá
tu-dy-úúvá
tu-mééná
tu-méénó
tu-méénó
tu-máaja
tu-moóla
tu-moóngu
tu-móóvá

ka-tivi

tu-tivi

tu-jóká

tu-túnu

tu-jela

tu-janí

\footnotetext{
9 This differs from the behavior of ma-, which, as was seen in (14), cannot be added before a fused class 5 prefix, e.g., *ma-dí-iná, *ma-dy-áaja, etc.
} 
For the purpose of comparison, see in (20) the diminutivization of nouns having vowel-initial stems but not belonging to class 5 . The stems of the nouns in (20a) have the shape -CVCV or longer. The prefixes of these nouns are not replaced by the diminutive prefixes. In contrast, in (20b) the prefixes of the nouns with vowel-initial stems keep their inherent noun class prefix in the diminutivization process. Thus, we can say that the double prefixation with vowel-initial stems is not specific to class 5 . The explanation of these facts has to be found in the syllable structure of the $-\mathrm{CV}-\mathrm{VCV}(\mathrm{CV})$ nouns.

(20) Stems (other than class 5)

a. - CVCV...

$\begin{array}{lllll}\text { n-sáku } & (3) & \text { 'bag' } & \text { ka-sáku } & \text { tu-sáku } \\ \text { ci-juni } & (7) & \text { 'bird' } & \text { ka-juni } & \text { tu-juni } \\ \text { n-gúku } & (9) & \text { 'hen' } & \text { ka-kúku } & \text { tu-kúku } \\ \text { n-kayidi } & (1) & \text { 'prisoner' } & \text { ka-kayidi } & \text { tu-kayidi } \\ \text { lu-kolomá } & (11) & \text { 'ditch' } & \text { ka-kolomá } & \text { tu-kolomá } \\ \text { wu-lombeelá } & (14) & \text { 'marriage' } & \text { ka-lombeelá } & \text { tu-lombeelá }\end{array}$
b. $-\mathrm{VCV}$...
Cl.12 (sg.)
$\mathrm{Cl} .13$ (pl.) $\quad \mathrm{Cl} .13$ (pl.) (alternative)
mw-iisi
mw-éésí
c-áálá
'pestle' ka-mw-iisi
tu-mw-iisi
tu-mi-isi
(3) 'moon'
ka-mw-éésí
tu-mw-éésí
tu-my-éésí
(7) 10 'finger'
ka-c-áálá
tu-c-áálá
tu-y-áálá
mw-aanáce (1)
'child'
ka-mw-aanáce
tu-mw-aanáce tu-va-anáce
c-eenjelele (7)
'soot'
ka-c-eenjelele
tu-c-eenjelele
tu-y-eenjelele
c-aanáasa
'mercy'
ka-c-aacáasa
tu-c-aanáasa
tu-y-aanáasa

The two ways of deriving a plural diminutive having a vowel-initial stem are illustrated in (21). 11
a. singular
diminutive
plural
dí-íná
ka-dí-íná
$\rightarrow \quad$ tu-dí-íná
mw-aanáce $\rightarrow$
ka-mw-aanáce
$\rightarrow$
tu-mw-aanáce
b. singular
plural
dí-íná
m-ééná
diminutive
mw-aanáce $\rightarrow$
va-anáce
$\rightarrow \quad$ tu-m-ééná
$\rightarrow$ tu-va-anáce

10 Class 7 ci-becomes cy-before a vowel, which is then simplified to the alveopalatal affricate [č].

11 Although we present a derivational account of the facts here, this is not a necessary feature of the analysis. The insight we wish to express is that the "correspondences" between the input noun and the derived plural diminutive may be perceived either as a pluralization of a derived diminutive or as a diminutivization of a plural. 
In (21a), we first diminutivize (by prefixing diminutive singular $k a$ - to the nouns) and then pluralize (by replacing the diminutive singular prefix $k a$ - by the corresponding plural tu-). In (21b) pluralization precedes diminutivization, in the sense that we first replace the normal singular marker $d i$ - by the normal plural marker ma-. Then we diminutivize by adding to the plural nouns the diminutive plural marker $t u$-. We thus see that there are two "paths" to plural diminutivization.

The order in which the diminutivization and pluralization processes are applied can be seen by the order of the inner prefixes present in the output. When diminutivization precedes pluralization, the end result presents the diminutive plural prefix attached to the inherent singular marker as in (21a). When pluralization precedes diminutivization the output comes with the diminutive marker attached to the inherent plural marker, as in (21b). The availability of two such paths to plural diminutivization is not evident with stems which begin with a consonant. In this case, both orders yield the correct results. 12

Now consider in (22) the diminutive of monosyllabic stems. In (22), we see that the diminutive prefixes $k a$ - and $t u$-, like the plural prefix ma-, cannot be directly prefixed to a class 5 monomoraic -CV stem. As a result, forms are obtained with the double prefixes $k a-d i i-$ and tu-dii-.

(22) - CV stem

Cl.5 (sg.)

$\mathrm{Cl} .12$ (sg.) Cl.13 (pl.)

Cl.13 (pl.)

(alternative)

$\begin{array}{ll}\text { dii-pé } & \text { 'spear grass' } \\ \text { dii-sí } & \text { 'side of a river' } \\ \text { dii-wú } & \text { 'ashes' }\end{array}$

ka-dii-pé tu-dii-pé

*tu-ma-dii-pé

ka-dii-sí tu-dii-sí *tu-ma-dii-sí

ka-dii-wú tu-dii-wú *tu-ma-dii-wú

In (23) we exemplify the two paths by which plural diminutives are formed from nouns having -CV stems.
a. singular
plural
diminutive
dii-pé
ma-dii-pé $\rightarrow$
tu-dii-pé
dii-wú

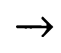
ma-dii-wú
$\rightarrow$
tu-dii-wú
b. singular
diminutive
plural
dii-pé
dii-wú
$\begin{array}{ll}\rightarrow & k a-d i i-p e ́ \\ & \text { ka-dii-wú }\end{array}$
$\rightarrow$
tu-dii-pé
tu-dii-wú

When ma-dii-pé is diminutivized, as in (23a), or when ka-dii-pé is pluralized, as in (23b), the outer prefix is replaced in the process. We therefore do not obtain

12 This fact can be seen in the following derivations yielding equivalent outputs:

(a) di-wiíwi 'chicken' $\rightarrow$ ka-wiíwi 'small chicken' $\rightarrow$ tu-wiíwi 'small chickens' (Dim $\supset$ Plur)

(b) di-wilwi 'chicken' $\rightarrow$ ma-wiľwi 'chickens' $\rightarrow$ tu-wüwi 'small chickens' (Plur $\supset$ Dim) 
forms with three prefixes, such as *tu-ma-dii-pé, since the bimoraic condition on the base to which $t u$ - is prefixed is met by the singular prefix dii-plus the monomoraic stem. Thus, ma- must be truncated as in other cases of diminutivization.

Consider next a set of data illustrating nouns having - CV stems but from classes other than class 5 . The process of diminutivizing is similar to what was seen in (20) and (21). The one difference is that plural prefixes such as mi- (cl.4) and $y i-(\mathrm{cl} .8)$ are attached directly to the stem (vs. class $6 \mathrm{ma}$ - which requires the singular prefix to be present).

(24) -CV stem (other than class 5)

\begin{tabular}{|c|c|c|c|c|}
\hline & & $\mathrm{Cl} .12$ (sg.) & Cl.13 (pl.) & $\begin{array}{l}\mathrm{Cl} .13 \text { (pl.) } \\
\text { (alternative) }\end{array}$ \\
\hline$m u-s i(3)$ & 'village' & $k a-m u-s i$ & $t u-m u-s i$ & $t u-m i-s i$ \\
\hline ci-pi (7) & 'darkness' & $k a-c i-p i$ & $t u-c i-p i$ & $t u-y i-p i$ \\
\hline ci-pó (7) & 'pimple' & $k a-c i-p o ́$ & tu-ci-pó & tu-yi-pó \\
\hline
\end{tabular}

There are, then, two possible paths (25) to forming plural diminutives: diminutivization may precede pluralization or, vice-versa, pluralization may precede diminutivization, though the resulting output differs. Both sets of output are wellformed, since $t u$-is followed by two moras. The derivation in (25) is similar to the one seen previously with vowel-initial stems in (21).
a. singular
diminutive
plural
$m u-s i$
$\rightarrow$ ka-mu-si
$\rightarrow$ tu-mu-si
ci-pó
$\rightarrow$ ka-ci-pó
$\rightarrow$ tu-ci-pó
b. singular
$\begin{array}{ll} & \text { plural } \\ \rightarrow & \text { mi-si } \\ & \text { yi-pó }\end{array}$
diminutive
mu-si
ci-pó
$\rightarrow$ tu-mi-si
$\rightarrow \quad$ tu-yi-pó

In this section we have seen that, while the $d i$-/dii-alternation has no independent effect on the diminutivization process, diminutivization on -CV noun stems is dependent on the mora count in the stem. We conclude from the data in (21), (22), and (24) that Ciyao diminutivizers cannot be attached directly to monomoraic stems. Rather, they are attached to a prefixed noun, thereby satisfying the minimality requirement of two moras. On the other hand, $\mathrm{ka-} / \mathrm{tu}$ are prefixed directly to stems if they are at least bimoraic. When the stem is vowel-initial, the rules which apply to $-\mathrm{CV}$ stems are expanded to these roots and double prefixation is obtained. This, we assume, is due to the fusion processes which take place at the boundary between the prefix and the -VCV stem. This conclusion can also be extended to Cimwera [Harries 1950, Stump 1992], which has some of the same properties as Ciyao, its closest relative. 
3.2. Morphologically conditioned allomorphy. Thus far we have shown that there are two allomorphs of class 5 prefix in Ciyao whose selection is prosodically conditioned based on mora count. In this section we will show how the occurrence of these allomorphs is, in some contexts, morphologically conditioned, based on the locativization process of class 5 nouns.

In Ciyao there are three locative class prefixes, namely, pa- (cl.16), $\mathrm{ku}$ (cl.17) and $m u$ - (cl.18), which roughly mean 'at', 'to', and 'in', respectively. In this section we investigate how the locative prefixes affect the morphology (and phonology) of class 5 nouns. Consider the forms in (26), where the locative prefixes pa-, $\mathrm{ku}$-, and $\mathrm{mu}$ - are prefixed to nouns which take monomoraic prefix di-.

(26) a. di-CVVCV stems

di-wüwi 'chicken'

Class 16

i. pa-di-wiíwi

ii. p-ee-wiíwi

di-kúuga 'group'

Class 16

i. pa-di-kúuga

ii. p-ee-kúuga

b. di- with longer stems

di-piikanilo 'ear'

Class 16

i. pa-di-piikanilo

ii. p-ee-piikanilo

di-puundúgulú 'cloud'

Class 16

i. pa-di-puundúgulú

ii. p-ee-puundúgulú
Class 17

ku-di-wiíwi

$k w-i i-w i u ́ w i$

Class 17

ku-di-kúuga

kw-ii-kúuga
Class 18

n'-di-wiíwi

mw-ii-wirwi

Class 18

n'-di-kúuga

mw-ii-kúuga
Class 17

ku-di-piikanilo

kw-ii-piikanilo

Class 17

ku-di-puundúgulú

$k w$-ii-puundúgulú
Class 18

n'-di-piikanilo

mw-ii-piikanilo

As shown in both (26a) and (26b), there are two acceptable ways of locativizing the respective nouns. In (i) we have the locativizer plus $d i$ - and in (ii) the locativizer plus $i$-. The same variation in form occurs when /di-/ is followed by a preconsonantal nasal, as in (27). 
(27) a. di- with moraic NC-initial stems

dii-mbáciiga 'swollen gland'

Class $16 \quad$ Class $17 \quad$ Class 18

i. pa-dii-mbáciiga ku-dii-mbáciiga n'-dii-mbáciiga

ii. p-ee-mbáciiga $\quad k w$-ii-mbáciiga $\quad m w$-ii-mbáciiga

dii-mbanaanga 'splendour'

Class $16 \quad$ Class $17 \quad$ Class 18

i. pa-dii-mbanaanga ku-dii-mbanaanga n'-dii-mbanaanga

ii. p-ee-mbanaanga $k w$-ii-mbanaanga mw-ii-mbanaanga

b. di- with non-moraic NC-initial stems

di-ngwíita 'bracelet'

Class 16

i. pa-di-ngwíita

ii. p-ee-ngwíita

di-mbaala 'gruel'

Class 16

i. pa-di-mbaala

ii. p-ee-mbaala
Class 17

ku-di-ngwíita

kw-ii-ngwíita

Class 17

ku-di-mbaala

kw-ii-mbaala
Class 18

n'-di-ngwita

mw-ii-ngwíita

Class 18

n'-di-mbaala

mw-ii-mbaala

The data in (26) and (27) thus show that, unlike pluralization via class 6 and diminutivization through classes 12 and 13 whose prefixes usually "replace" the inherent noun class prefix, locative prefixes are always attached to the nouns and not to the stems. This fact suggests that we look at the locatives as secondary prefixes "par excellence". Semantically, they provide secondary, adverbial, information about the noun they are attached to-localization in space or timeand, morphologically, they do not interfere significantly with the structure of the noun. The word significantly is important here because, as shown in (ii), the affixation of the locatives to the class 5 nouns appears to trigger an optional deletion of the consonant of the class 5 prefix through a process which can be represented as in (28).

$$
\begin{aligned}
& \mathrm{pa}+\mathrm{di} \rightarrow \text { pai } \rightarrow \text { pee (cl.16) } \\
& \mathrm{ku}+\mathrm{di} \rightarrow \text { kui } \rightarrow \text { kwii (cl.17) } \\
& \mathrm{mu}+\mathrm{di} \rightarrow \text { mui } \rightarrow \text { mwii (cl.18) }
\end{aligned}
$$

The derivational schema in (28) illustrates our analysis in which a d-deletion rule applies optionally to the class 5 prefix when locative prefixes are attached to class 5 nouns. As a consequence, the inherent class 5 prefix vowel is left unprotected and fuses with the locative prefix, triggering the regular rules of 
vowel coalescence $a+i \rightarrow$ ee (when the locative marker is pa-) and gliding $u+i$ $\rightarrow$ wii (when the locative marker is $k u$ - or $m u-$ ). No other noun class prefix may delete its consonant under locativization as does class 5 , as illustrated by the examples in (29).

\begin{tabular}{|c|c|c|c|c|}
\hline$m u u-n d u(1)$ & 'person' & $\begin{array}{l}\text { Class } 16 \\
\text { i. pa-muu-ndu } \\
\text { ii. }{ }^{*} p-o o-n d u\end{array}$ & $\begin{array}{l}\text { Class } 17 \\
k u-m u u-n d u \\
* k u-u-n d u\end{array}$ & $\begin{array}{l}\text { Class } 18 \\
m-m u u-n d u \\
{ }^{*} m u-u-n d u\end{array}$ \\
\hline vaa-ndu (1) & 'persons' & $\begin{array}{l}\text { i. pa-vaa-ndu } \\
\text { ii. *pa-a-ndu }\end{array}$ & $\begin{array}{l}k u-v a a-n d u \\
* k w-a a-n d u\end{array}$ & $\begin{array}{l}m u-v a a-n d u \\
* m w-a a-n d u\end{array}$ \\
\hline mu-si (3) & 'village' & $\begin{array}{l}\text { i. pa-mu-si } \\
\text { ii. }{ }^{*} p-o o-s i\end{array}$ & $\begin{array}{l}k u-m u-s i \\
{ }^{*} k u-u-s i\end{array}$ & $\begin{array}{l}m u-m u-s i \\
{ }^{*} m u-u-s i\end{array}$ \\
\hline mi-si (4) & 'villages' & $\begin{array}{l}\text { i. } p a-m i-s i \\
\text { ii. *p-ee-si }\end{array}$ & $\begin{array}{l}k u-m i-s i \\
{ }^{*} k w-i-s i\end{array}$ & $\begin{array}{l}m-m i-s i \\
{ }^{*} m-i-s i\end{array}$ \\
\hline ma-wútá (6) & ‘oil' & $\begin{array}{l}\text { i. pa-ma-wútá } \\
\text { ii. *pa-a-wútá }\end{array}$ & $\begin{array}{l}\text { ku-ma-wútá } \\
{ }^{*} k w-a-w u ́ t a ́\end{array}$ & $\begin{array}{l}\text { m-ma-wútá } \\
\text { *mw-a-wútá }^{\text {mo- }}\end{array}$ \\
\hline ci-tútu (7) & 'ashpit' & $\begin{array}{l}\text { i. pa-ci-tútu } \\
\text { ii. *p-ee-tútu }\end{array}$ & $\begin{array}{l}\text { ku-ci-tútu } \\
*_{k w-i-t u ́ t u}\end{array}$ & 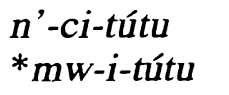 \\
\hline yi-tútu (8) & 'ashpits' & $\begin{array}{l}\text { i. pa-yi-tútu } \\
\text { ii. }{ }^{*} p \text {-ee-tútu }\end{array}$ & $\begin{array}{l}\text { ku-yi-tútu } \\
{ }^{*} k w-i-t u ́ t u\end{array}$ & $\begin{array}{l}\text { n’-yi-tútu } \\
\text { *mw-i-tútu }^{2}\end{array}$ \\
\hline m-bwá $(9 / 10)$ & ${ }^{\prime} \operatorname{dog}(s) '$ & $\begin{array}{l}\text { i. paa-m-bwá } \\
\text { ii. *pa-bwá }\end{array}$ & $\begin{array}{l}\text { kuu-m-bwá } \\
{ }^{*} k u-b w a ́\end{array}$ & $\begin{array}{l}\text { muu-m-bwá } \\
{ }^{*} m u-b w a ́\end{array}$ \\
\hline lu-kújú (11) & 'fig' & $\begin{array}{l}\text { i. pa-lu-kújú } \\
\text { ii. *p-oo-kújú }\end{array}$ & $\begin{array}{l}\text { ku-lu-kújjú } \\
{ }^{*} k u-u-k u ́ j u ́\end{array}$ & $\begin{array}{l}\text { n'-nu-kújú } \\
\text { *mu-u-kújú }\end{array}$ \\
\hline ka-pwá (12) & 'puppy' & $\begin{array}{l}\text { i. pa-ka-pwá } \\
\text { ii. * }{ }^{*} \text { a-a-pwá }\end{array}$ & $\begin{array}{l}k u-k a-p w a ́ \\
* k w-a-p w a ́\end{array}$ & $\begin{array}{l}\text { n'-ka-pwá } \\
*^{*} m w-a-p w a ́\end{array}$ \\
\hline tu-wúpá (13) & 'sm. bones' & $\begin{array}{l}\text { i. pa-tu-wúpá } \\
\text { ii. *p-oo-wúpá }\end{array}$ & $\begin{array}{l}\text { ku-tu-wúpá } \\
{ }^{*} k u-u-w u ́ p a ́\end{array}$ & $\begin{array}{l}\text { n'-tu-wúpá } \\
\text { *mu-u-wúpá }\end{array}$ \\
\hline Wu-úji (14) & 'gruel' & $\begin{array}{l}\text { i. pa-wu-úji } \\
\text { ii. }{ }^{*} p-o o-u ́ j i\end{array}$ & $\begin{array}{l}k u-w u-u ́ j i \\
{ }^{*} k u-u-u ́ j j i\end{array}$ & $\begin{array}{l}m u-w u-u ́ j i \\
{ }^{*} m u-u-u ́ j i\end{array}$ \\
\hline
\end{tabular}

With this fact established, let us consider examples of class 5 nouns which take bimoraic prefix dii- (30). Here we observe that the process of affixation of locative prefixes to class 5 nouns whose prefixes are bimoraic does not differ from what we saw in (26) and (27). Again there are two acceptable ways of locativizing a class 5 nominal. It would thus appear that the number of moras in the prefix does not affect the output of affixation of locative prefixes to class 5 nouns. 
(30) a. dii- with -CVCV stems

\begin{tabular}{|c|c|c|c|c|}
\hline dii-tivi & 'valley' & $\begin{array}{ll} & \text { Class } 16 \\
\text { i. } & \text { pa-dii-tivi } \\
\text { ii. } & p \text {-ee-tivi }\end{array}$ & $\begin{array}{l}\text { Class } 17 \\
\text { ku-dii-tivi } \\
k w \text {-ii-tivi }\end{array}$ & $\begin{array}{l}\text { Class } 18 \\
\text { n'-dii-tivi } \\
\text { mw-ii-tivi }\end{array}$ \\
\hline dii-jóká & 'snake' & $\begin{array}{l}\text { i. pa-dii-jóká } \\
\text { ii. p-ee-jóká }\end{array}$ & $\begin{array}{l}\text { ku-dii-jóká } \\
k w \text {-ii-jóká }\end{array}$ & $\begin{array}{l}\text { n'-dii-jóká } \\
\text { mw-ii-jóká }\end{array}$ \\
\hline
\end{tabular}

b. dii- with -CVCVVNCV stem
Class 16
Class 17
Class 18

dii-pujuungu 'vapor' i. pa-dii-pujuungu ku-dii-pujuungu n'-dii-pujuungu

ii. p-ee-pujuungu $k w$-ii-pujuungu mw-ii-pujuungu

Affixation of the locatives to the bimoraic class 5 prefix raises the question of what is deleted. Is it the consonant /d/ as was suggested above or it is the full mora di-? While we have spoken of a rule of d-deletion thus far, the facts in (30) suggest another hypothesis which is truer to the historical events that produced this situation. Recall from $\S 1$ that Meeussen reconstructs $*_{i-}$ as the class 5 noun prefix and an augment + prefix sequence $*$ di- $i-$. Our hypothesis is that we do not have a rule of d-deletion, but rather a specific class 5 allomorph $i$ - that shows up only under locativization. This allomorphy produces the output forms in (31).

(31) $\begin{array}{lllllll}\mathrm{pa}+ & -\mathrm{i} & \rightarrow & \mathrm{pa}-\mathrm{i} & \rightarrow & \text { pee } & (\mathrm{cl} .16) \\ \mathrm{ku}+ & -\mathrm{i} & \rightarrow & \mathrm{ku}-\mathrm{i} & \rightarrow & \mathrm{kwii} & (\mathrm{cl} .17) \\ \mathrm{mu}+ & -\mathrm{i} & \rightarrow & \mathrm{mu}-\mathrm{i} & \rightarrow & \text { mwii } & (\mathrm{cl} .18)\end{array}$

Although Ciyao has lost the historical Bantu augment, historically *pa-, *ku-, and $*$ mu- replaced the augment $*$ di- that preceded the prefix $*_{i}$-. Or, put slightly differently, locative prefixes were followed by augmentless prefixes: pa- $i^{-}$, not pa-di-i-. Since other cases of dii- have been reanalyzed as monomorphemic (conditioned by mora count), we suggest a further restructuring whereby $i$ became a third allomorph of the class 5 prefix in present-day Ciyao: When preceded by one of the above three locative prefixes, a class 5 noun prefix which is normally $d i$ - or dii- (determined by prosodic considerations) can optionally be i-. 13

13 As pointed out to me by Larry Hyman (pers. comm.), a similar allomorphy di-/i-appears in Kinande where the normal class 5 prefix di-surfaces as $i$ - rather than $d i$ - when the class 5 noun is localitivized. So, in both languages there is historical evidence that the class 5 prefix vowel which surfaces when the noun is locativized is a relic of the Proto-Bantu $*_{i-}$. The major difference between the two languages however, is that in Kinande di-and $i$ - are in complementary distribution. The allomorph di-never surfaces after locative prefix, contexts where allomorph $i$ - is the only realization regardless of the structure of the noun stem. In Ciyao, as mentioned above, the vestige of Proto-Bantu $*_{j}$ - appears optionally only when the noun stem is at least bimoraic and has a consonant in stem-initial position. Another language where we find a similar situation is Luba-Kasai. In this language the class 5 prefix has two allomorphs, $i$ - and di-. The former occurs optionally, just like in Ciyao, with some forms of locative [Kadima, 1969:38] and the latter occurs elsewhere. 
From the analysis presented here we can conclude that the class 5 prefix has three allomorphs in Ciyao, listed in (32).

$$
\begin{aligned}
& \text { Class } 5 \rightarrow \text { i- / locative } \\
& \text { dii- / _ noun stem }[\mu(\mu)] \\
& \text { di- / elsewhere }
\end{aligned}
$$

To complete this discussion, consider locativization of class 5 nouns with -VCV stems given in (33).
-VCV stems
a. dí-íná 'name'
dí-ínó 'tooth'
dí-ísó 'eye'
Class 16
i. pa-dí-íná
ii. *p-ee-ná
Class 17
Class 18
ku-dí-íná
n'-dí-íná
*kw-ii-ná
*mw-ii-ná
i. pa-dí-ínó
ii. ${ }^{*} p$-ee-nó
ku-dí-ínó
n'-dí-ínó
*kw-ii-nó
*mw-ii-nó
i. pa-dí-ísó
ii. *p-ee-só
ku-di-ísó
${ }^{*} k w-i i-s o ́$
n'-dí-ísó
*mw-ii-só
pa-dy-aája ku-dy-aája $\quad n^{\prime}$-dy-aája pa-dy-oóla ku-dy-oóla n'-dy-oóla pa-dy-uúngu ku-dy-uúngu n'-dy-uúngu pa-dy-úúvá ku-dy-úúvá n'-dy-úúvá pa-dy-óogo ku-dy-óogo n'-dy-óogo pa-dy-óósí $\quad k u$-dy-óósí n'-dy-óósí

In this case there is only one correct result: prefixation of pa-, $k u-$, or $n$ '- to the fused class 5 prefix $d i$ - or $d y$-. These data may be interpreted as further evidence that the "unprotected" vowel /i/ is a relic of class 5 prefix $*_{i-}$ and not part of di- which remains behind when /d/ is deleted. As proposed by Hyman and Katamba [1997], it appears that * di- was also used as the basic class 5 prefix before stems beginning with a vowel-whether inherited from Proto-Bantu or obtained by deletion of $* \mathrm{j}$. Thus, the reason we fail to obtain intermediate forms

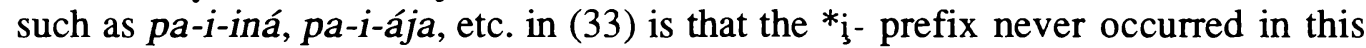
position. Synchronically, what this means is that there must be a further condition on the first allomorph in (32), which must not be available when the following noun stem is vowel-initial.

Compare this with the locativization of nouns having - CV stems. The data in (34) behave like those in (33); the locative prefix can only be attached to the class 5 dii- allomorph. The data in (34b) constitute evidence that locatives are attached not only to class 5 nouns, but to nouns belonging to any class, without deleting the prefix. 
a. - CV stem (class 5)

Class $16 \quad$ Class $17 \quad$ Class 18

\begin{tabular}{|c|c|c|c|c|}
\hline dii-pé & 'spear grass' & $\begin{array}{l}\text { i. pa-dii-pé } \\
\text { ii. *p-ee-pé }\end{array}$ & $\begin{array}{l}\text { ku-dii-pé } \\
* k w-i i-p e ́\end{array}$ & $\begin{array}{l}\text { n'-dii-pé } \\
*^{*} m w-i i-p e ́\end{array}$ \\
\hline dii-sí & 'side of a river' & $\begin{array}{l}\text { i. pa-dii-sí } \\
\text { ii. } p-e e-s i\end{array}$ & $\begin{array}{l}\text { ku-dii-sí } \\
* k w-i i-s i\end{array}$ & $\begin{array}{l}n^{\prime} \text {-dii-sí } \\
*^{\prime} m w-i i-s i ́\end{array}$ \\
\hline dii-wú & 'ashes' & $\begin{array}{l}\text { i. pa-dii-wú } \\
\text { ii. }{ }^{*} p-e e-w u ́\end{array}$ & $\begin{array}{l}k u-d i i-w u ́ \\
* k w-i i-w u ́\end{array}$ & $\begin{array}{l}n^{\prime}-d i i-w u ́ \\
*^{*} m w-i i-w u ́\end{array}$ \\
\hline
\end{tabular}

b. -CV stem (other than class 5)

$\begin{array}{lllll}m u-s i(3) & \text { 'village' } & \text { pa-mu-si } & k u-m u-s i & m \text {-mu-si } \\ \text { ci-pi (7) } & \text { 'darkness' } & \text { pa-ci-pi } & k u-c i-p i & n \text {-ci-pi } \\ \text { ci-pó (7) } & \text { 'pimple' } & \text { pa-ci-pó } & k u-c i-p o ́ & n \text {-ci-pó }\end{array}$

A comparison of the data in (33)-(34) on the one hand, with those in (26)(27) and (30) on the other hand, allows us to see that locatives do not discriminate among nouns in terms of the mora count. Both in (26)-(27) and (30) and in (33)(34), locative prefixes are attached to nouns through the inherent prefix regardless of the number of moras in the noun stem. However, it is important to note that, with the exception of $p$-ee-sí (33a) which means 'across', the third class 5 allomorph $i$-never surfaces when the stem is monomoraic. That is, if the noun stem has fewer than two moras, the $i$ - allomorph is not available. Thus the complete statement on the $i$-allomorph must be as in (35).

$$
\text { Class } 5 \rightarrow \text { i- / locative }-[\mathrm{C} \mu \mu . . .] \text { (optional) }
$$

The class 5 prefix may optionally be spelled out as $i$ - if it is preceded by a locative prefix and if its stem begins with a consonant and contains at least two moras. ${ }^{14}$

14 In the interest of completeness, we note that locative and diminutive prefixes can co-occur in the same word not only with the primary prefixes (di- and ma-in our case), but also with each other, as in the following examples:

(a) pa-ka-dinnó 'at the small tooth' pa-tu-dyuúngu 'at the small pumpkins'

pa-tu-diiwú 'at the small ashes'

pa-kaa-mbanaanga 'at the small light'

pa-tu-páta

'at the sm. temp. dams'

(b) ku-ka-dínó

ku-tu-dyuúngu

ku-tu-diiwú ku-kaa-mbanaanga ku-tu-páta 'to the small tooth'

'to the small pumpkins'

'to the small ashes'

'to the small light'

'to the sm. temp. dams' (c) n-ka-dúnó

n-tu-dyuúngu

n-tu-diiwú

n-kaa-mbanaanga

n-tu-páta 'in the small tooth'

'in the small pumpkins'

'in the small ashes'

'in the small light'

'in the small temporary dams' 


\section{Conclusion}

From the preceding discussion we conclude the following about Ciyao:

First, class 5 has three allomorphs, namely, $i-$, which surfaces optionally after locatives when the noun stems are consonant-initial and at least bimoraic; dii-, which is prosodically conditioned (requiring that the noun stem be bimoraic at most); and monomoraic di-, which occurs elsewhere.

Second, the diminutive prefixes $k a-$ and $t u$ - behave like class 6 prefix ma-in that they count the number of moras in the stem before their affixation. If the noun stem contains at least two moras, the diminutive prefixes are attached to the stems. If the noun stem is subminimal (i.e., monomoraic), $k a-$ or $t u$-is attached to the full noun (i.e., inherent prefix + stem).

Third, locatives behave as genuine secondary prefixes. They are always attached to full nouns, not to the stems, regardless of the number of the moras in the stem.

\section{REFERENCES}

Clements, George N. 1986. "Compensatory Lengthening and Consonant Gemination in Luganda." In L. Witzel and E. Sezer (Eds.), Studies in Compensatory Lengthening. Dordrecht: Foris, 37-77.

De Blois, Kees F. 1970. "The augment in Bantu languages." Africana Linguistica IV: 85-165. Tervuren: Musée Royal de l'Afrique Centrale.

Guthrie, Malcolm. 1967-71. Comparative Bantu. Farnborough, Englsand: The Gregg International Publishers.

Harries, Lyndon. 1950. A Grammar of Mwera. Johannesburg: Witwatersrand University Press.

Hayes, Bruce. 1989. "Compensatory lengthening in moraic phonology." Linguistic Inquiry 20, 2: 153-306.

The order in which the prefixes appear on the surface forms cannot be reversed. From the observation of the examples above it is reasonable to conclude that among the secondary prefixes a distinction is necessary to draw between those which are attached at the lexical level and those that are added postlexically. In the former group we could have the diminutives and in the latter the locatives. We thus can propose that primary prefixes are added at a stratum 1 , diminutives prefixes at stratum 2 , and locative prefixes (proclitics?) at stratum 3, i.e. as per their surface order. 
Hayes, Bruce. 1989. "Compensatory lengthening in moraic phonology." Linguistic Inquiry 20, 2: 153-306.

Hubbard, Katheen. 1993. "The Manifestation of Vowel Quantity: A Comparative Study." Paper presented at the 24th ACAL, The Ohio State University.

Hubbard, Katheen. 1994. Duration in Moraic Theory. Ph.D. dissertation, UC Berkeley.

Hubbard, Katheen, 1995. "Towards a theory of phonological and phonetic timing: evidence from Bantu. In Bruce Connell and Amalia Arvaniti (eds.), Phonology and Phonetics Evidence. Papers in Phonology Laboratory IV. Cambridge: Cambridge University Press. Pp. 168-187.

Hyman, Larry M. 1985. A Theory of Phonology Weight. Dordrecht: Foris Publications.

Hyman, Larry M. and Francis X. Katamba. 1997. "The syllable in Luganda phonology and morphology." MS.

Hyman, Larry M. and Armindo Ngunga. 1994. "On non-universality of tonal association 'conventions': evidence from Ciyao." Phonology 11-25-68.

Hyman, Larry M. and Armindo S. A. Ngunga. 1997. "Two kinds of moraic nasal in Ciyao. Studies in African Linguistics 26, 2:131-163.

Kadima, Marcel. 1969. Le systeme des classes en bantou. Leuven: Vander.

McCarthy, J. and A. Prince. 1995. "Faithfulness and reduplicative identity." Papers in Optimality Theory. University of Massachusetts Occasional Papers in Linguistics 18.249-384.

Maddieson, Ian. 1993. "Spliting the Mora." UCLA Working Papers in Phonetics 83:9-18.

Maddieson, Ian and Peter Ladefoged. 1993. "Phonetics of partially nasal consonants." In Marie K. Huffmann and Rena Krakow (eds.), Phonetics and Phonology 5: 251-301.

Meeussen, A. E. 1967. "Bantu grammatical recontructions." Africana Linguistica 3: 81-121. Tervuren: Musée Royale de l'Afrique Centrale. Annales-Sciences Humaines, Série IN-8, No. 121. 
Ngunga, Armindo S. A. 1987. "A comparison of Shona and Yao noun classes." MS. Harare: University of Zimbabwe.

Ngunga, Armindo S. A. 1995. "Phonetics and phonology of vowel length in Ciyao.” MS. Berkeley: University of California.

Stump, Gregory T. 1992. "The adjacency condition and formation of dimnutives in Mwera and Kikuyu." In Laura A. Buszard-Welcher, Lionel Wee, and William Weigel (eds.), Proceedings of the 18th Annual Meeting of the BLS: general session, Berkeley: Pp. 441-452.

Sanderson, G. Meredith. 1922. A Yao Grammar. London: Society for Promoting Christian Knowledge.

Sanderson, G. Meredith. 1954. Yao Dictionary. Zomba, Malawi: Government Printer.

Whiteley, W.H. 1961. Shape and Meaning in Yao Nominal Classes. ALS ii. ????

Whiteley, W.H. 1966. A Study of Yao Sentences. Oxford: Oxford University Press.

Department of Linguistics

[Received June, 1997;

University of California accepted August, 1997]

Berkeley, CA 94720

asangu@uclink.berkeley.edu 